Studia nad Autorytaryzmem i Totalitaryzmem 43, nr 3

Wrocław 2021

https://doi.org/10.19195/2300-7249.43.3.11

\author{
MARTA WOŹNIAK \\ ORCID: 0000-0003-0021-6760 \\ Uniwersytet Opolski \\ mwozniak@uni.opole.pl
}

\title{
Konstrukcja prawna planowania przestrzennego w Polsce w latach 1945-1989
}

\author{
Słowa kluczowe: konstrukcja prawna, planowanie przestrzenne, interes społeczny, hierarchia \\ aktów planowania.

\section{THE LEGAL CONSTRUCTION OF SPATIAL PLANNING IN POLAND BETWEEN 1945 AND 1989}

\begin{abstract}
The main objective of this paper is to present the legal construction of the spatial planning in Poland between 1945 and 1989, as well as its evaluation from the perspective of the development of spatial planning and management legislation. The thesis put forward in the paper is that between 1945 and 1989, i.e. in the years when the principle of self-governance was not supported by state institutions, spatial planning was detached from the needs of local communities. Analyzing the legal construction of the spatial planning in Poland between 1945 and 1989 showed a certain regularity, namely that the spatial order construction was difficult at that time due to the then socio-economic conditions resulting in the centrally controlled spatial development and a hierarchy of spatial planning acts. The paper indicates that in those years, there was a connection between spatial planning and building law, but it was not as strong as in the interwar period. The connotations with the environmental law in turn manifested themselves in the downplaying of environmental issues in spatial planning. The article shows that in the years 1945-1989, there was little interest from the legislator in the category of public interest, which at the time became known as "social interest".
\end{abstract}

Keywords: legal construction, spatial planning, public interest, hierarchy of planning acts. 


\section{Wprowadzenie}

Pierwsze dojrzałe regulacje prawne $\mathrm{z}$ zakresu planowania przestrzennego w Polsce datuje się na okres dwudziestolecia międzywojennego, ale zalążków planowego zagospodarowania można doszukać się już w XIX wieku1. W doktrynie poświęconej prawnym aspektom kształtowania się ładu przestrzennego na ziemiach polskich postawiono tezę, że rozwój polskiej myśli planistycznej nakłada się na rozwój administracji. W okresie kiedy samorząd terytorialny w Polsce przestał istnieć, zaobserwować można bowiem wyraźny regres w budowaniu ładu przestrzennego. $Z$ kolei rozkwitowi samorządu terytorialnego towarzyszy rozwinięte, bogate $w$ elementy partycypacji społecznej planowanie przestrzenne ${ }^{2}$. $Z$ tej tezy można wywieźć kolejną — że w latach 1945-1989, w których zasada samorządności nie miała oparcia $\mathrm{w}$ instytucjach państwa, planowanie przestrzenne było oderwane od potrzeb miejscowych społeczności.

Celem niniejszego artykułu jest przedstawienie konstrukcji prawnej planowania przestrzennego w Polsce w latach 1945-1989 i jej ocena z perspektywy rozwoju ustawodawstwa $\mathrm{w}$ dziedzinie planowania przestrzennego. W budowaniu prawnej koncepcji planowania przestrzennego w tym okresie, mimo wielu barier spowodowanych ówczesnym ustrojem społeczno-gospodarczym, można zaobserwować pojawianie się materialnoprawnych konotacji z prawem budowlanym i prawem ochrony środowiska, które nota bene pozostały do dzisiaj. Z naukowego punktu widzenia interesujące jest również uwypuklenie przedmiotowego zagadnienia w płaszczyźnie interesu publicznego (wówczas społecznego). Przedstawienie problematyki należy poprzedzić geopolitycznym tłem regulacji.

\section{Polityczno-prawne uwarunkowania planowania przestrzennego po drugiej wojnie światowej}

Bezpośrednio po drugiej wojnie światowej pierwsze koncepcje planistyczne oparte na podejściu geograficznym, nawiązujące do przedwojennej polskiej myśli urbanistycznej, nie zostały zaakceptowane przez władze komunistyczne. Planowanie przestrzenne zostało podporządkowane planowaniu gospodarcze$\mathrm{mu}$, co wynikało z priorytetowego traktowania interesów poszczególnych branż przemysłowych i gospodarczych, a nie jednostek terytorialnych lub regionów ${ }^{3}$. Wpływ nadmiernego uprzemysłowienia w czasach reżimu komunistycznego

1 Więcej na ten temat zob. Z. Leoński, M. Szewczyk, Zasady prawa budowlanego i zagospodarowania przestrzennego, Bydgoszcz-Poznań 2002, s. 20-23.

2 Por. M. Woźniak, Tradycja prawna budowania tadu przestrzennego w Polsce, „Przegląd Legislacyjny” 2011, nr 2-4, s. 80.

3 G. Węcławowicz et al., Przestrzenne zagospodarowanie Polski na początku XXI wieku, Warszawa 2002, WA51_13507_r2006-nr6_Monografie.pdf(dostęp: 12.04.2021), s. 16. 
i nienadążającej za nim urbanizacji pogłębiał zarysowujący się w tym czasie kryzys planowania przestrzennego. Towarzyszyło temu charakterystyczne dla ustroju komunistycznego ignorowanie uwarunkowań przyrodniczych, co skutkowało dużym zanieczyszczeniem środowiska i degradacją polskiego krajobrazu 4 .

Kształtowanie ładu przestrzennego według filozofii przyspieszonej urbanizacji było spowodowane potrzebą odbudowy kraju ze zniszczeń wojennych i stworzenia społeczeństwu warunków bytowych oraz możliwości zarobkowania. Mimo propozycji prawno-urbanistycznych racjonalne postulaty planowania przestrzennego najczęściej pozostawały w formie deklaratywnej, a decydujący i ostateczny wpływ na decyzje lokalizacyjne i sposób zagospodarowania terenów miały władze komunistyczne. W praktyce scentralizowany model gospodarki planowej oderwany był od potrzeb lokalnych. Dominacja planowania gospodarczego nad planowaniem przestrzennym sprzyjała interesom władz komunistycznych, które mogły w ten sposób realizować swoją wizję państwa, niepokrywającą się z interesem jednostek. W 1950 roku został zlikwidowany samorząd terytorialny ${ }^{5}$, a jego miejsce zastąpiły rady narodowe, $w$ wyniku czego planowanie przestrzenne utraciło charakter samorządowy, władztwo zaś nad przestrzenią przejęły organy administracji państwowej.

W okresie PRL podstawy prawne planowania przestrzennego były wielokrotnie zmieniane, także pod wpływem reformatorskich nurtów, które cyklicznie pojawiały się na fali politycznych odwilży. Zmiany te nie mogły mieć z oczywistych powodów głębokiego i trwałego charakteru, przełamującego ustrojowe i polityczne pryncypia realnego socjalizmu ${ }^{6}$. System planowania przestrzennego, który obowiązywał w latach 1945-1989, opisano w literaturze trwałymi cechami konstytutywnymi, charakterystycznymi dla tego okresu, uwzględniając przy tym trafnie tło geopolityczne, a mianowicie:

1. planowanie w ogóle, ale zwłaszcza planowanie gospodarcze, było traktowane jako wyróżnik ustrojowy państwa socjalistycznego, a wszelkie propozycje reform były odrzucane z powodów ideologicznych;

2. planowanie było instrumentem nakazowo-rozdzielczego systemu sterowania rozwojem; cechowało się scentralizowaniem i powiązaniem hierarchicznym;

3. planowy charakter gospodarki narodowej oznaczał, że realizacja zamierzeń wyrażanych w planach przestrzennych była w decydującym stopniu warunkowana środkami ustalanymi w dyrektywnych planach gospodarczych;

${ }^{4}$ P. Śleszyński, T. Markowski, A. Kowalewski, Uwarunkowania i przyczyny chaosu przestrzennego, „Studia KPZK” 182, 2018, Studia nad chaosem przestrzennym, https://journals.pan.pl/ skpzk/125273 (dostęp: 12.04.2021).

5 Zob. ustawa z dnia 20 marca 1950 r. o terenowych organach jednolitej władzy państwowej, Dz.U. Nr 14, poz. 130 ze zm.

${ }^{6}$ B. Kolipiński et al., Planowanie przestrzenne. Stan i problemy ze szczególnym uwzględnieniem ochrony środowiska i ocen oddziaływania na środowisko, „Zeszyty Naukowe” 2, 2010, s. 12. 
4. w planowaniu główne znaczenie miał układ pionowy, działowo-resortowy, w którego ramach zapadały decyzje o kluczowych dla gospodarki inwestycjach, łącznie z ustalaniem ich lokalizacji;

5. układy poziome tworzyło planowanie terenowe i przestrzenne, które pozostawało w gestii rad narodowych; słabsza względem układu resortowego pozycja planowania terenowego wynikała $\mathrm{z}$ zakresu jego kompetencji (głównie gospodarka komunalna i mieszkaniowa) oraz z pozycji politycznej rad narodowych, które funkcjonowały w ramach tak zwanych jednolitych organów władzy państwowej, co w praktyce oznaczało, że nie były one samodzielnymi podmiotami polityki przestrzennej i gospodarczej ${ }^{7}$.

U schyłku budowania powojennej koncepcji planowania przestrzennego z pewnym sentymentem można było wspominać dojrzałe jak na owe czasy rozporządzenie Prezydenta Rzeczypospolitej z dnia 16 lutego 1928 roku o prawie budowlanym i zabudowie osiedli ${ }^{8}$, w którym połączone zostały dwie grupy zagadnień: wymogi dotyczące przestrzennego zagospodarowania oraz wymogi odnoszące się do technicznych aspektów procesu budowlanego ${ }^{9}$. Ten przyjęty w owym czasie standard ${ }^{10}$ nigdy później, ani w okresie reżimu komunistycznego, ani nawet po 1989 roku, nie został powtórzony mimo pojawiających się kilkakrotnie prób, które kończyły się w najlepszym razie zazębianiem się regulacji planowania przestrzennego i prawa budowlanego.

Po drugiej wojnie światowej rozporządzenie z 1928 roku zastąpione zostato dekretem z dnia 2 kwietnia 1946 roku o planowym zagospodarowaniu przestrzennym kraju ${ }^{11}$, któremu towarzyszyły dwa inne dekrety ${ }^{12}$. Odtąd problematyka planowania przestrzennego stała się przedmiotem odrębnej regulacji, choć proces ten następował stopniowo i wiązał się z dążeniem do podporządkowania wszelkiej działalności w przestrzeni, zarówno podmiotów prywatnych, jak i państwa, planom zagospodarowania przestrzennego ${ }^{13}$. Zgodnie z art. 1 dekretu z dnia 2 kwietnia 1946 roku o planowym zagospodarowaniu przestrzennym kraju wszelkie poczynania publiczne i prywatne w zakresie rozmieszczenia ludności lub wykorzystania terenu miały być dostosowane do postanowień planów miejscowych, planów regionalnych i planu krajowego. Plany te stanowiły hierarchiczny system aktów prawnych: plan krajowy tworzył podstawę sporządzenia planów regionalnych, te ostatnie zaś były podstawą do sporządzenia planów miejscowych ${ }^{14}$.

7 Ibidem, s. $12-13$.

8 Dz.U. R.P. nr 23, poz. 202.

9 Z. Leoński, M. Szewczyk, op. cit., s. 25.

10 Zob. Z. Niewiadomski, Planowanie przestrzenne. Zarys systemu, Warszawa 2003, s. 17.

11 Dz.U. R.P. nr 16, poz. 109.

12 Dekret o państwowym planie inwestycyjnym z 1946 r. i dekret o planowej gospodarce narodowej z $1947 \mathrm{r}$.

13 H. Izdebski, I. Zachariasz, Ustawa o planowaniu i zagospodarowaniu przestrzennym, Warszawa 2013, komentarz LEX, s. 25.

14 Ibidem. 
Akty te miały wiele słabości, przede wszystkim zaś cechował je brak elastyczności w planowaniu przestrzeni bardzo osłabionej działaniami wojennymi. Cechą charakterystyczną tych przepisów był ścisły związek między planowaniem przestrzennym a planowaniem gospodarczym. Plany zagospodarowania przestrzennego były zsynchronizowane z narodowymi planami gospodarczymi zarówno co do terminów realizacji, jak i pod względem treści ${ }^{15}$. Zdaniem badacza zagadnień planistycznych i środowiskowych W. Brzezińskiego plany gospodarcze i plany przestrzenne dotyczyły w istocie zbliżonych zagadnień, jednakże pierwsze ustalały cele gospodarki narodowej, wskazywały środki potrzebne do ich realizacji oraz rozkładały związane $\mathrm{z}$ tym procesy $\mathrm{w}$ czasie, natomiast drugie te same zagadnienia rozkładały w przestrzeni ${ }^{16}$.

Nurt w planowaniu przestrzennym utworzony na kanwie dekretu $\mathrm{z}$ dnia 2 kwietnia 1946 roku o planowym zagospodarowaniu przestrzennym kraju opierał się na kilku założeniach:

1. wzajemnej pionowej zależności planowania przestrzennego: najpierw był uchwalany plan krajowy, następnie plany regionalne, a na końcu plany miejscowe;

2. obligatoryjności planowania przestrzennego na wszystkich szczeblach, to jest obowiązku sporządzenia planów miejscowych dla wszystkich osiedli, a planów regionalnych dla wszystkich regionów oraz planu krajowego;

3. hierarchiczności strukturalnej organów planowania przestrzennego i przyznaniu kompetencji do uchwalania planów miejscowych radom narodowym oraz

4. powiązaniu planowania przestrzennego z planowaniem gospodarczym ${ }^{17}$.

Nurt ten zapoczątkował łączenie planowania przestrzennego z potrzebami gospodarki narodowej, co stwarzało w owym czasie pozory ochrony przestrzeni i budowania ładu przestrzennego. W latach pięćdziesiątych i sześćdziesiątych zjawisko to nasiliło się i znalazło formalnoprawny wyraz w treści ustawy z dnia 31 stycznia 1961 roku o planowaniu przestrzennym ${ }^{18}$.

W okresie reżimu komunistycznego można zaobserwować wspomniane już zazębianie się regulacji planowania przestrzennego i prawa budowlanego. Także i współcześnie ustawy te tworzą funkcjonalną całość, składającą się na szeroko rozumiany proces inwestycyjny. W tym samym dniu 31 stycznia 1961 roku uchwalona została ustawa Prawo budowlane ${ }^{19}$, ale na realny związek realizacji inwestycji z planami miejscowymi wskazano dopiero ustawie z dnia 24 października

15 Zob. Z. Niewiadomski, op. cit., s. 18-19.

16 Zob. W. Brzeziński, Podstawy prawne planowania gospodarczego i przestrzennego, Warszawa 1948, s. 95-96.

17 P. Sosnowski, Ochrona ładu przestrzennego w Polsce przed 2003 r. Przyczynek do wykładni historycznej, [w:] Ochrona ładu przestrzennego z perspektywy prawno-urbanistycznej, red. M.J. Nowak, Warszawa 2020, s. 80-81.

18 Dz.U. Nr 7, poz. 47.

19 Ustawa z dnia 31 stycznia 1961 r. Prawo budowlane, Dz.U. Nr 7, poz.46 ze zm. 
1974 roku Prawo budowlane ${ }^{20}$. Przeprowadzoną ustawą z dnia 28 maja 1975 roku $^{21}$ reformą podziału administracyjnego kraju wprowadzono w Polsce dwustopniowy podział administracyjny, wskutek czego system planistyczny, będący wynikową tych reform, dał władzy państwowej pełnię panowania nad przestrzenią wraz z instrumentami prawnymi ${ }^{22}$. Co więcej, po 1975 roku na centralistyczny system administrowania przestrzenią nałożyła się dodatkowo ta niekorzystna okoliczność, iż wobec zlikwidowania dużych województw zniknęło też planowanie regionalne.

Uchwalona w dniu 12 lipca 1984 roku ustawa o planowaniu przestrzennym ${ }^{23}$ była $\mathrm{w}$ istocie kontynuacją zapoczątkowanej w Polsce po drugiej wojnie światowej wizji zarządzania gospodarczego, w której interes państwa przeważał nad interesem właściciela, zainteresowanego ustaleniami planu zagospodarowania przestrzennego ${ }^{24}$. Z drugiej strony, mimo iż odzwierciedlała ona centralistyczny system planowania, zawierała pewne nowatorskie pomysły ${ }^{25}$. Wprowadzała nowy rodzaj planów zagospodarowania przestrzennego - plany obszarów funkcjonalnych. Opracowywano je między innymi ze względu na wyjątkowe walory ekologiczne danego obszaru (na przykład dla obszaru parku narodowego lub krajobrazowego), występujące na obszarze wykraczającym poza zasięg planu miejscowego lub regionalnego. Ustawa ta określała też niedoskonałe jeszcze mechanizmy uspołeczniania procesów planowania przestrzennego ${ }^{26}$.

Jednocześnie w tym czasie zaczęło się rozwijać prawo ochrony środowiska, które znalazło swój normatywny wydźwięk w ustawie z dnia 31 stycznia 1980 roku o ochronie i kształtowaniu środowiska ${ }^{27}$. Ustawa ta dała niewątpliwie podwaliny współczesnego systemu prawa ochrony środowiska w Polsce, ale sama ochrona środowiska, podobnie zresztą jak planowanie przestrzenne, w okresie komunistycznym nie była traktowana priorytetowo. Fala forsownej industrializacji w latach siedemdziesiątych przyczyniła się do gwałtownego pogorszenia jakości środowiska i znaczącego wzrostu presji wywieranej na nie przez przemysł i urbanizację ${ }^{28}$. W systemie autorytarnym państwo było zarówno właścicielem

20 Dz.U. Nr 38, poz. 229 ze zm.

21 Ustawa o dwustopniowym podziale administracyjnym Państwa oraz o zmianie ustawy o radach narodowych, Dz.U. z 1975 r. Nr 16, poz. 91.

22 Por. M. Kulesza, Gminne planowanie przestrzenne a inwestycje prywatne, [w:] Kierunki rozwoju prawa administracyjnego. Podstawowe zagadnienia prawa budowlanego i planowania przestrzennego, Poznań 1999, s. 266.

23 Dz.U. Nr 35, poz. 185 z późn. zm.

24 Zob. M. Kulesza, Gminne planowanie..., s. 265.

25 Zob. P. Kwaśniak, Plan miejscowy w systemie zagospodarowania przestrzennego, Warszawa 2009 , s. 36.

26 Więcej na ten temat zob. ibidem, s. 38-39.

27 Dz.U. z 1994 r. Nr 49, poz. 196 ze zm.

28 Z. Karaczun Analiza ewolucji instrumentów polityki ekologicznej w polskim systemie zarządzania ochrona środowiska oraz ocena potrzeby nowych narzędzi, [w:] 100 lat ochrony środowiska w Polsce, red. W. Szymalski, Radom 2020, s. 65. 
podmiotów zanieczyszczających i regulatorem ich działalności ${ }^{29}$, jak i jedynym pomysłodawcą i wykonawcą urządzania przestrzeni.

\section{Ustawa z dnia 31 stycznia 1961 roku o planowaniu przestrzennym jako podstawowe ogniwo planowania przestrzennego w okresie reżimu komunistycznego}

Po drugiej wojnie światowej polską myśl planistyczną opanował pogląd, że tylko centralne sterowanie rozwojem i włączenie planowania przestrzennego w planowanie gospodarcze może tworzyć ramy działań umożliwiające racjonalne zagospodarowanie kraju, jego regionów i poszczególnych jednostek osadniczych.

Centralistyczny model planowania przestrzennego uwypuklał cel planowania zawarty w art. 1 ustawy z dnia 31 stycznia 1961 roku o planowaniu przestrzennym, którym było ustalenie dla poszczególnych obszarów przeznaczenia i sposobu zagospodarowania terenów, z uwzględnieniem potrzeb bieżących i przyszłych wynikających z programu rozwoju gospodarczego i społecznego. Ustalenia te z kolei miały być oparte na planach perspektywicznych rozwoju gospodarki narodowej oraz na wieloletnich narodowych planach gospodarczych. Nie miały więc charakteru samodzielnego, lecz były ściśle zintegrowane z planowaniem gospodarczym państwa.

Koncepcja prawna planowania przestrzennego w myśl tej ustawy miała trójstopniową strukturę: planowanie państwa odbywało się za pośrednictwem planów rozwoju gospodarki narodowej, planowanie województw lub ich części następowało w ramach planów perspektywicznych rozwoju województw lub ich części, tak zwanych planów regionalnych, z kolei dla obszarów poszczególnych jednostek osadniczych lub ich części - w ramach miejscowych planów zagospodarowania przestrzennego, zwanych planami miejscowymi. Ustawodawca zdefiniował przy tym jednostkę osadniczą, przyjmując, że jest nią miasto, wieś lub inna miejscowość, która stanowi skupienie budynków mieszkalnych i wraz z powiązanymi z nimi urządzeniami produkcyjnymi i usługowymi tworzy określone środowisko życia ludności.

Konstrukcja planowania przestrzennego na obszarze jednostek osadniczych opierała się na występowaniu dwóch rodzajów planów: ogólnych i szczegółowych. Zgodnie z art. 12 ustawy z dnia 31 stycznia 1961 roku o planowaniu przestrzennym miejscowymi planami zagospodarowania przestrzennego były ogólne plany zagospodarowania przestrzennego jednostek osadniczych oraz szczegółowe plany zagospodarowania przestrzennego części jednostek osadniczych.

Plan ogólny, w zasadzie sporządzany dla wszystkich jednostek osadniczych, cechował się ścisłym związkiem merytorycznym i czasowym z wieloletnim narodowym planem gospodarczym. Określał podstawowe kierunki i skalę rozwoju

29 Ibidem, s. 65-66. 
oraz zasady zagospodarowania przestrzennego terenu na cały okres planu, jak też program i sposób zagospodarowania przestrzennego jednostki osadniczej w okresie najbliższego wieloletniego narodowego planu gospodarczego. Tworzył podstawę gospodarki terenami i ustalania potrzeb inwestycyjnych na obszarze danej jednostki osadniczej. Zasadniczo projekt planu ogólnego był sporządzany dla całego obszaru objętego zamierzeniami zagospodarowania danej jednostki osadniczej, ale w uzasadnionych przypadkach plan ogólny może być sporządzony również dla wyodrębnionej części miasta.

Dla części obszaru jednostki osadniczej przewidzianej do zagospodarowania (zabudowy, odbudowy, przebudowy) na podstawie ustaleń planu ogólnego sporządzany był plan szczegółowy, który podobnie jak plan ogólny był sporządzany w okresie bieżącego i najbliższego wieloletniego narodowego planu gospodarczego; był więc z nim zintegrowany czasowo. Jak sama nazwa wskazuje, plan szczegółowy określał szczegółowo przeznaczenie terenów na poszczególne cele, wyznaczał linie rozgraniczające te tereny, ustalał zasady uzbrojenia i urządzenia terenu, określał linię zabudowy oraz dopuszczalną wysokość zabudowy, a w miarę potrzeby też inne warunki i wytyczne kształtowania zabudowy. Miał więc plan szczegółowy cechy zbliżone do współczesnego miejscowego planu zagospodarowania przestrzennego, jednakże okoliczności jego wydawania były zgoła odmienne.

Regulacja ta w istocie kontynuowała zapoczątkowane tuż po drugiej wojnie światowej mechanizmy zagospodarowania przestrzeni. Nie straciło na aktualności czasowe i treściowe powiązanie planowania przestrzennego z planowaniem gospodarczym. Pod rządami ustawy z 1961 roku planowanie przestrzenne miało wówczas jeszcze jeden istotny mankament, a mianowicie pozbawione było kontroli społecznej; akceptacja przez władzę wykonawczą i państwową była wystarczająca. Wprawdzie w myśl art. 22 ust. 3 zainteresowane osoby fizyczne i prawne mogły składać uwagi i wnioski do projektu planu miejscowego, jednak w praktyce ich rola była iluzoryczna. Najczęściej plany były odczytywane przez społeczeństwo jako dodatkowy instrument represji, za pomocą którego następowało wywłaszczenie. Paradoksalnie w owym czasie, mimo znacznego ograniczenia uprawnień obywateli i wątpliwego statusu jednostki, w wysokim stopniu utrzymała się prywatna własność terenów rolnych oraz terenów budowlanych. Jednocześnie utrwalały się niedemokratyczne praktyki planistyczne, dla których logika ładu przestrzennego kojarzona była wyłącznie z budową osiedli mieszkaniowych.

\section{Impuls do zmian w planowaniu przestrzennym — ustawa $\mathrm{z}$ dnia 12 lipca 1984 roku o planowaniu przestrzennym ${ }^{30}$}

Mimo utrzymania trójszczeblowej struktury planowania przestrzennego i zasady hierarchiczności planów w ustawie z dnia 12 lipca 1984 roku o planowaniu

30 Dz.U. z 1984 r. Nr 35, poz. 185 z późn. zm. 
przestrzennym dokonała się pewna zmiana jakościowa: ustalono priorytety planowania przestrzennego, wyraźne wskazując cel ukierunkowany na polepszenie jakości życia, zachowanie równowagi przyrodniczej i ochronę dóbr kultury. Zwrócono uwagę na ciągłość planowania przestrzennego, które powinno być procesem obejmującym nie tylko oceny stanu zagospodarowania przestrzennego, lecz także opracowanie prognoz. Ochronie przestrzeni służyło zniesienie okresu obowiązywania planów miejscowych (ustawodawca stwierdził jedynie, że plany zagospodarowania przestrzennego sporządza się jako plany długookresowe) ${ }^{31}$ przy jednoczesnym utrzymaniu zasady obligatoryjności sporządzania planów ogólnych. Nadal utrzymywał się jednolity i niepodzielny system administracji państwowej z wyraźnym podporządkowaniem instytucji terenowych instytucjom centralnym, co nie pozostawało bez wpływu na władztwo planistyczne. Tym samym planowanie przestrzenne zostało planowaniem państwowym bez realnego wpływu na sytuację prawną podmiotów indywidualnych. Usankcjonowana prawnie współzależność planowania przestrzennego z planowaniem społeczno-gospodarczym nie pozostawiała złudzeń co do utrzymania dotychczasowego modelu kształtowania przestrzeni. Na realną zmianę trzeba było poczekać do dnia 1 stycznia 1995 roku, albowiem dopiero ustawą z dnia 7 lipca 1994 roku o zagospodarowaniu przestrzennym ${ }^{32}$ nastąpiło odejście od hierarchicznej struktury planowania przestrzennego, zerwanie z zasadą obligatoryjności planów i wprowadzenie mechanizmów społecznych w planowaniu, co miało oczywisty związek z przebudową ustrojową państwa. Można więc skonstatować, że obiecujący art. 1 ustawy traktujący o celu planowania i art. 2 wprowadzający zasadę ciągłości planowania $^{33}$ dał pewien impuls do zmian, jednak duch komunistycznego planowania gospodarczego utrzymał się aż do przemian ustrojowych.

\section{Interes publiczny (społeczny) w planowaniu przestrzennym w latach 1945-1989}

Głównym zagadnieniem prawa planowania i zagospodarowania przestrzennego po 1945 roku stała się kwestia zgodności zamierzeń inwestycyjnych podmiotów indywidualnych i gospodarczych z ustaleniami planów zagospodarowania przestrzennego, natomiast wymóg realizacji inwestycji infrastrukturalnych jako warunku sine qua non realizacji zabudowy mieszkaniowej, usługowej czy produkcyjnej przestał być, co mogło znaleźć uzasadnienie w deklarowanym modelu gospodarki planowej ${ }^{34}$, obowiązkiem prawnym i pozostał $\mathrm{w}$ istocie kwestią

31 P. Sosnowski, op. cit., s. 90.

32 Dz.U. z 1999 r. Nr 15, poz. 139 ze zm.

33 Na temat ciągłości planowania przestrzennego zob. A. Brzezińska-Rawa, Spójność i ciagłość podstawowych aktów planowania przestrzennego. Aspekty prawne, Toruń 2019.

34 Więcej na ten temat zob. J. Sommer, Charakter prawny planów w zakresie ochrony środowiska, „Ochrona Środowiska - Prawo i Polityka” 2010, nr 2(60), s. 30 n. 
swobodnego działania administracji publicznej ${ }^{35}$. Jednocześnie w czasach reżimu komunistycznego w planowaniu przestrzennym widoczna była przewaga interesu społecznego nad indywidualnym, co było reminiscencją ówczesnego trendu politycznego i miało związek z brakiem struktur samorządowych. Skupienie władzy w całości w rękach organów władzy państwowej sprawiło, że administracja przestała „realizować swoje zadania w interesie publicznym, natomiast zaczęła realizację zadań w interesie społecznym"36. W doktrynie można spotkać poglądy, że pojęcie interesu społecznego określane było w przeszłości różnie: interes publiczny, interes społeczny, dobro wspólne z tendencjami do preferowania któregoś z określeń w danym czasie ${ }^{37}$. Należy zgodzić się z M. Kuleszą, że wyeliminowanie pojęcia interesu publicznego $\mathrm{z}$ języka prawnego i prawniczego i zastąpienie go u progu lat pięćdziesiątych pojęciem interesu społecznego nie było tylko sprawą terminologii prawniczej, ale miało inne, głębsze, przyczyny ${ }^{38}$. W okresie komunistycznym istniało ponadto niebezpieczeństwo utożsamiania interesu publicznego z interesem państwa. Tendencje te nie utrzymały się do przełomu lat 1989/1990, gdy podmiotowość prawną uzyskały jednostki samorządu terytorialnego.

Na zakres pojęcia interesu publicznego w planowaniu przestrzennym miały wpływ przemiany ustrojowe, praktycznie od okresu międzywojennego. Dekret z 1946 roku, który tworzył podstawę planowania przestrzennego aż do 1961 roku, nie wskazywał wartości planowania przestrzennego ani nie nawiązywał do konstrukcji interesu społecznego. Podobnie ustawa z dnia 31 stycznia 1961 roku o planowaniu przestrzennym nie wskazywała wartości, jakie powinny być uwzględniane w planowaniu przestrzennym, określając jedynie w typowy dla tego okresu cel planowania przestrzennego jako zapewnienie prawidłowego rozwoju poszczególnych obszarów kraju, z uwzględnieniem ich wzajemnych związków i interesów ogólnokrajowych oraz ustalenie prawidłowych współzależności przestrzennych między urządzeniami produkcyjnymi i usługowymi na tych obszarach i stworzenie w ten sposób warunków do rozwoju produkcji, wszechstronnego zaspokajania potrzeb ludności oraz ochrony naturalnych bogactw i walorów przyrodniczych kraju. Tak ujmowany cel planowania koncentrował się na interesie państwa, który ze względu na ówczesne uwarunkowania polityczne i społeczno-gospodarcze nie mógł być traktowany na równi z interesem publicznym. Nawet wzmianka o ,wszechstronnym zaspakajaniu potrzeb ludności” nasuwająca skojarzenia z działaniem w interesie publicznym, nie mogła być za taki uznana ${ }^{39}$. Dominacja

35 H. Izdebski, I. Zachariasz, op. cit., s. 25.

36 M. Wyrzykowski, Pojęcie interesu społecznego w prawie administracyjnym, Warszawa 1986, s. 26.

37 W. Szwajdler, Ochrona interesu indywidualnego w procesie budowlanym, Torun 1993, s. 26.

38 M. Kulesza, Administracyjnoprawne uwarunkowania polityki przestrzennej, Warszawa 1987, s. 58.

${ }^{39}$ M. Woźniak, Interes publiczny $i$ interes indywidualny $w$ planowaniu $i$ zagospodarowaniu przestrzennym, Opole 2019, s. 122. 
planowania gospodarczego nad planowaniem przestrzennym sprzyjała $\mathrm{w}$ gruncie rzeczy interesom państwa. Nie można zgodzić się z poglądem, że pojęcie interesu publicznego w tym okresie było nazbyt wąskie, aby objaśnić „,szerokie zadania państwa i jego organów, związane z organizowaniem nowego ładu społecznego, szczególnie w sferze odnoszącej się do materialnych warunków życia społecznego w sferze zarządzania gospodarczego" 40 . Interes publiczny w warunkach reżimu komunistycznego nie był właściwie pojmowany i nie obejmował potrzeb ogólnospołecznych, stwarzając pozory działania władzy państwowej w interesie ogólnym ${ }^{41}$.

Mimo pewnego impulsu do zmian w planowaniu przestrzennym wymagania interesu publicznego (społecznego) nie zostały uwzględnione w okresie obowiązywania ustawy z dnia 12 lipca 1984 roku o planowaniu przestrzennym, która była swoistą kontynuacją zapoczątkowanej w Polsce po drugiej wojnie światowej wizji zarządzania gospodarczego, w której interes państwa przeważał nad interesem właściciela ${ }^{42}$. I choć w art. 3 pkt 2 tej ustawy wskazano kilka wartości, które wspólnie wypełniają postulat interesu publicznego (uwzględnienie wymagań w zakresie ochrony zdrowia ludzi, ochrony środowiska, a w szczególności ochrony zasobów wodnych i energetycznych, złóż kopalin, gruntów rolnych i leśnych oraz ochrony dóbr kultury, a także wymagania związane z obronnością i bezpieczeństwem), interes publiczny jako taki nie został uwzględniony. W miejsce pojęcia interesu publicznego pojawiły się dwa inne pojęcia: interes ogólny i interes miejscowy. Kategoria interesu publicznego w planowaniu przestrzennym nie była w latach 1945-1990 dostrzeżona. Dopiero wraz z odejściem od gospodarki centralnie planowanej na rzecz zdecentralizowanego planowania przestrzennego i przywróceniem samorządności na ziemiach polskich ustawodawca dostrzegł potrzebę uwzględnienia interesu publicznego $\mathrm{w}$ planowaniu przestrzennym jako samodzielnej wartości. Rozwój przestrzeni i zmiany w obszarze praw i wolności obywatelskich związane ze zmianami ustrojowymi przełomu lat 1989/1990 stworzyły podwaliny wzmocnienia koncepcji interesu publicznego, ale i ochrony praw podmiotowych w procesie planistycznym.

\section{Podsumowanie}

Konstrukcja prawna planowania przestrzennego w latach 1945-1989 wpisywała się w ówczesny nurt ustrojowy, tworząc pionowy, hierarchiczny i pozbawiony udziału społecznego model. Charakter prawny i oddziaływanie poszczególnych instrumentów planowania przestrzennego na życie człowieka oparte na centralistycznym układzie administracji i gospodarki nie sprzyjały tworzeniu warunków do budowy ładu przestrzennego ani nie tworzyły warunków do ochrony

40 M. Kulesza, Administracyjnoprawne uwarunkowania..., s. 79.

41 M. Woźniak, Interes publiczny..., s. 123.

42 M. Kulesza, Gminne planowanie przestrzenne..., s. 265. 
interesu publicznego i interesu jednostkowego. Interes publiczny (wówczas społeczny), był w okresie reżimu komunistycznego pojmowany wąsko jako interes państwa, a nie interes zbiorowości.

Analiza prawodawstwa planistycznego tego okresu prowadzi do wniosku, że ówczesnemu prawodawcy przyświecała szlachetna idea nadania planowaniu przestrzennemu charakteru sprzyjającego interesowi społecznemu. Z perspektywy czasu ocena, czy obrano słuszną drogę, wiążąc planowanie przestrzenne z planowaniem gospodarczym, musi być dokonywana z uwzględnieniem specyfiki przemian społeczno-gospodarczych i gradacji potrzeb, wśród których na pierwszy plan wysuwała się odbudowa państwa po zniszczeniach wojennych. Władztwo organów państwowych nad przestrzenią z dzisiejszej perspektywy miało charakter iluzoryczny, ale w owym czasie logika planowania, zdominowana politycznym układem sił, opierała się na innych przesłankach i motywach. Postkomunistyczne planowanie przestrzenne odcięło się od wcześniejszych archaicznych koncepcji planistycznych, ale impulsem do zmian była dopiero zmiana ustrojowa przełomu lat 1989/1990 i utworzenie struktur samorządu terytorialnego.

\section{Bibliografia}

Brzezińska-Rawa A., Spójność i ciagłość podstawowych aktów planowania przestrzennego. Aspekty prawne, Torun 2019.

Brzeziński W., Podstawy prawne planowania gospodarczego i przestrzennego, Warszawa 1948.

Izdebski H., Zachariasz I., Ustawa o planowaniu i zagospodarowaniu przestrzennym, Warszawa 2013, komentarz LEX.

Leoński Z., Szewczyk M., Zasady prawa budowlanego i zagospodarowania przestrzennego, Bydgoszcz-Poznań 2002.

Karaczun Z., Analiza ewolucji instrumentów polityki ekologicznej w polskim systemie zarządzania ochrona środowiska oraz ocena potrzeby nowych narzędzi, [w:] 100 lat ochrony środowiska w Polsce, red. W. Szymalski, Radom 2020.

Kolipiński B., Radziejowski J., Skorupski J., Szulczewska B., Planowanie przestrzenne. Stan i problemy ze szczególnym uwzględnieniem ochrony środowiska i ocen oddziaływania na środowisko, „Zeszyty Naukowe” 2, 2010.

Kulesza M., Administracyjnoprawne uwarunkowania polityki przestrzennej, Warszawa 1987.

Kulesza M., Gminne planowanie przestrzenne a inwestycje prywatne, [w:] Kierunki rozwoju prawa administracyjnego. Podstawowe zagadnienia prawa budowlanego i planowania przestrzennego, Poznań 1999.

Kwaśniak P., Plan miejscowy w systemie zagospodarowania przestrzennego, Warszawa 2009.

Niewiadomski Z., Planowanie przestrzenne. Zarys systemu, Warszawa 2003.

Sommer J., Charakter prawny planów w zakresie ochrony środowiska, „Ochrona Środowiska - Prawo i Polityka” 2010, nr 2 (60).

Sosnowski P., Ochrona ładu przestrzennego w Polsce przed 2003 r. Przyczynek do wyktadni historycznej, [w:] Ochrona ładu przestrzennego z perspektywy prawno-urbanistycznej, red. M.J. Nowak, Warszawa 2020.

Szwajdler W., Ochrona interesu indywidualnego w procesie budowlanym, Torun 1993. 
Śleszyński P., Markowski T., Kowalewski A., Uwarunkowania i przyczyny chaosu przestrzennego, „Studia KPZK” 182, 2018, Studia nad chaosem przestrzennym, https://journals.pan.pl/skpzk/ 125273.

Węcławowicz G., Bański J., Degórski M., Komornicki T., Korcelli P., Śleszyński P., Przestrzenne zagospodarowanie Polski na początku XXI wieku, Warszawa 2002, WA51_13507_r2006-nr6_ Monografie.pdf.

Woźniak M., Interes publiczny i interes indywidualny w planowaniu i zagospodarowaniu przestrzennym, Opole 2019.

Woźniak M., Tradycja prawna budowania ładu przestrzennego w Polsce, „Przegląd Legislacyjny” 2011, nr 2-4.

Wyrzykowski M., Pojęcie interesu społecznego w prawie administracyjnym, Warszawa 1986.

\section{Akty prawne}

Ustawa z dnia 20 marca 1950 r. o terenowych organach jednolitej władzy państwowej, Dz.U. Nr 14, poz. $130 \mathrm{ze} \mathrm{zm}$.

Ustawa z dnia 31 stycznia 1961 r. o planowaniu przestrzennym, Dz.U. Nr 7, poz. 47 ze zm.

Ustawa z dnia 31 stycznia 1961 r. Prawo budowlane, Dz.U. Nr 7, poz. 46 ze zm.

Ustawa z dnia 24 października 1974 r. Prawo budowlane, Dz.U. Nr 38, poz. 229 ze zm.

Ustawa z dnia 28 maja 1975 r. o dwustopniowym podziale administracyjnym Państwa oraz o zmianie ustawy o radach narodowych, Dz.U. z 1975 r. Nr 16, poz. 91.

Ustawa z dnia 31 stycznia 1980 r. o ochronie i kształtowaniu środowiska, Dz.U. z 1994 r. Nr 49, poz. 196 ze zm.

Ustawa z dnia 12 lipca 1984 r. o planowaniu przestrzennym, Dz.U. z 1984 r. Nr 35, poz. 185 ze zm.

Ustawa z dnia 7 lipca 1994 r. o zagospodarowaniu przestrzennym, Dz.U. z 1999 r. Nr 15, poz. 139 ze zm.

Rozporządzenie Prezydenta Rzeczypospolitej z dnia 16 lutego 1928 r. o prawie budowlanym i zabudowie osiedli, Dz.U. R.P. nr 23, poz. 202. 